\title{
Recruitment variation in Macoma balthica: a laboratory examination of the match/mismatch hypothesis
}

\author{
Oscar G. Bos*, Catharina J. M. Philippart, Gerhard C. Cadée, Jaap van der Meer
}

Department of Marine Ecology and Evolution, Royal Netherlands Institute for Sea Research, PO Box 59, 1790 AB Den Burg, The Netherlands

\begin{abstract}
Long-term observation (1973 to 2001) of recruitment in the intertidal bivalve Macoma balthica (L.) in the western Wadden Sea has revealed that interannual variation in recruitment may be possibly governed by match/mismatch mechanisms. Mismatch occurs when spawning takes place before or at the beginning of the spring phytoplankton bloom, whereas matching occurs when spawning takes place during the spring bloom. To test the match/mismatch hypothesis, a laboratory experiment was conducted in which 6 batches of $M$. balthica larvae were reared at different starting times during a phytoplankton spring bloom (April to May 2002). Larvae were reared in Wadden Sea seawater with the natural phytoplankton assemblage at 2 larval concentrations. As controls, larvae of the same batches were reared in filtered seawater with Isochrysis galbana. A clear effect of fertilisation date on larval growth and development rates was observed, which however could not be explained by phytoplankton concentration differences. In addition, no effects of fertilisation date or food level on mortality were detected. Hence, in this experiment, larval performance was affected by the timing of spawning, although the underlying mechanisms remain unclear.
\end{abstract}

KEY WORDS: Bivalve larvae $\cdot$ Food limitation $\cdot$ Development $\cdot$ Phytoplankton

\section{INTRODUCTION}

The match/mismatch hypothesis of Cushing (1975) states that variability in fish recruitment is caused by annual variation in temporal and/or spatial overlap between fish larvae and prey. The underlying assumptions are: (1) that spawning occurs at a fixed time with little annual variation and (2) that prey reproduction is coupled to primary production, which varies on a yearly basis due to environmental stochasticity. Therefore, a match or mismatch of the larvae with primary production would result in varying levels of starvation and subsequent survival (Cushing 1990).

The existence of such a match/mismatch of larvae and their prey has predominantly been investigated and demonstrated for commercial fish species, usually by correlating field data on prey concentrations with recruit densities (review in Cushing 1990, Fortier et al.
1995, Platt et al. 2003), or by subjecting larvae to different feeding conditions (e.g. Gotceitas et al. 1996). In contrast, little is known about the relation between larval food availability and recruitment in bivalves (review in Olson \& Olson 1989), although Phillips (2002) provides evidence for negative effects of low larval food availability on age and size at metamorphosis and post-settlement growth.

Philippart et al. (2003) have shown in a correlation study that the variation in recruitment of the intertidal bivalve Macoma balthica in the Wadden Sea may be partly due to a match/mismatch of larvae and phytoplankton. A mismatch may occur when temperatureinduced spawning (Lammens 1967) takes place before or at the start of the light-induced phytoplankton bloom (Cadée 1986), while a match occurs when spawning is induced after the start of the phytoplankton bloom. 
The aim of the present study was to investigate the existence of a match/mismatch of Macoma balthica larvae and the phytoplankton on which they feed in the Wadden Sea, as suggested by Philippart et al. (2003). For this purpose a 2-factor experiment was used in which fertilisation date and food level were varied. The fertilisation date was varied by fertilising M. balthica eggs at different dates within the spawning season of the bivalve. The food level was varied by rearing the larvae in seawater taken directly from the Wadden Sea (2 levels of phytoplankton) or in filtered seawater enriched with Isochrysis galbana (control level). Effects on growth, development rate, and mortality of larvae were estimated. It was hypothesised that a mismatch would occur early in the season, when phytoplankton concentrations were low, while a match would occur later in the season, when algal concentrations were high. A mismatch was predicted to result in increased larval mortality, low growth rates and a restricted development.

\section{MATERIALS AND METHODS}

General methods. Mature adult Macoma balthica were collected from the Mok Bay (Texel, The Netherlands, $53^{\circ} 00^{\prime} \mathrm{N}, 4^{\circ} 45^{\prime} \mathrm{E}$ ) in March 2002 and stored at $5^{\circ} \mathrm{C}$ in aerated basins $(50 \times 40 \times 10 \mathrm{~cm})$ prefilled with sandy sediment. Each basin contained about 100 individuals. To keep them in good condition, the animals were fed 3 times $\mathrm{wk}^{-1}$ with a mixture of concentrated algae (Isochrysis galbana and Tetraselmis sp.; Reed Mariculture). To prepare food for the M. balthica larvae, a continuous culture of I. galbana was set up in the laboratory at $15^{\circ} \mathrm{C}$.

Production and maintenance of larvae. Individual Macoma balthica were induced to spawn in April and May 2002, and the procedure followed was that of Honkoop et al. (1999). On average, about $40 \%$ of the adults spawned. Fertilisation was carried out by pipetting eggs of several females into a beaker and adding 1 to $3 \mathrm{ml}$ of sperm suspension derived from 1 or more males. The resultant mixture was left undisturbed overnight at $15^{\circ} \mathrm{C}$. Fertilised eggs (diameter approximately $100 \mu \mathrm{m}$ ) were then separated from all other matter by rinsing them over stacked sieves of 120 and $50 \mu \mathrm{m}$. Subsequently, they were transferred into 11 glass bottles containing filtered $(1 \mu \mathrm{m})$ and UV-irradiated seawater (UVFS) dosed with $1.5 \times 10^{-5} \mathrm{~g} \mathrm{l}^{-1}$ Penicillin $\mathrm{G}$ potassium salt and $2.5 \times 10^{-5} \mathrm{~g} \mathrm{l}^{-1}$ streptomycin sulphate (Drent 2002). The bottles were placed on a roller-table (2 to $3 \mathrm{rpm}$ ) and maintained at $15^{\circ} \mathrm{C}$. At Day 3 the majority of larvae had reached the D-stage.

Experimental set-up. The experiment consisted of 2 treatments examining: (1) the fertilisation date and
(2) the food level (Table 1). The fertilisation date was varied by rearing 6 batches of larvae (A, B, C, D, E and $\mathrm{F})$ at different moments in the natural spawning season of Macoma balthica (April to May) (Table 1). Three food levels were applied to the D-larvae (6 replicates per food level). The first food level (SW1) consisted of $50 \mu \mathrm{m}$ filtered natural seawater, which was collected at high tide $\left(53^{\circ} 01^{\prime} \mathrm{N}, 4^{\circ} 48^{\prime} \mathrm{E}\right)$. The concentration of larvae in SW1 was set at 1 larva $\mathrm{ml}^{-1}$. The second food level (SW5) was identical to that of SW1, but the concentration of larvae was set at 5 larvae $\mathrm{ml}^{-1}$, i.e. per capita food levels were $20 \%$ of those in SW1. The third food level (control) consisted of UVSF enriched with $5.0 \times 10^{4}$ cells ml ${ }^{-1}$ of Isochrysis galbana. The concentration of larvae was set at 1 larva $\mathrm{ml}^{-1}$. In total, 18 different combinations of fertilisation date and food level were obtained (Table 1). To keep the larvae in suspension, the replicates (300 $\mathrm{ml}$ glass bottles) were placed on a roller-table (4 to $5 \mathrm{rpm}$ ). During the experiment, the seawater was changed 3 times $\mathrm{wk}^{-1}$. Replicates were taken out of the experiment to perform growth and development measurements, after which they were preserved with 5 to $10 \%$ formalin to determine larval concentrations (see below). The temperature was kept constant at $15^{\circ} \mathrm{C}$.

Larval food availability. A $20 \mathrm{ml}$ sample of natural seawater was taken for phytoplankton analysis (details in Cadée 1986), each time the water was refreshed. Phytoplankton taxa with a maximum length of $20 \mu \mathrm{m}$ were selected for further analysis, since the average larval shell length in this experiment was $192 \pm 0.7 \mu \mathrm{m}$ (mean $\pm \mathrm{SE}, \mathrm{n}=2392$ ) and Macoma balthica larvae probably only ingest food particles up to the diameter of their mouth, i.e. up to $20.5 \pm 0.4$ (mean $\pm \mathrm{SE}, \mathrm{n}=15)$ for larvae of $184.9 \pm$ $9.2 \mu \mathrm{m}(\mathrm{n}=15)$ (J. van Iperen pers. comm.). Food availability for each batch was calculated by determining the average number of palatable phytoplankton cells $\mathrm{ml}^{-1}$ for the $21 \mathrm{~d}$ rearing period.

Table 1. Experimental set-up. For each of the 18 combinations ( 6 fertilisation dates $\times 3$ food levels), the number of replicates is indicated. SW1: natural seawater, 1 larva $\mathrm{ml}^{-1}$; SW5: natural seawater, 5 larvae $\mathrm{ml}^{-1}$; control: filtered seawater enriched with Isochrysis galbana (50000 cells ml ${ }^{-1}$ )

\begin{tabular}{|c|c|c|c|c|}
\hline \multicolumn{2}{|c|}{$\begin{array}{l}\text { Treatment 1: } \\
\text { fertilisation date }\end{array}$} & \multicolumn{3}{|c|}{$\begin{array}{l}\text { Treatment 2: } \\
\text { food level }\end{array}$} \\
\hline Code & Date 2002 & SW1 & SW5 & Control \\
\hline A & $4 \mathrm{Apr}$ & 5 & 5 & 5 \\
\hline B & $8 \mathrm{Apr}$ & 6 & 5 & 6 \\
\hline C & 15 Apr & 6 & 5 & 6 \\
\hline D & $22 \mathrm{Apr}$ & 6 & 3 & 6 \\
\hline E & 29 Apr & 6 & 6 & 6 \\
\hline F & 9 May & 6 & 6 & 6 \\
\hline
\end{tabular}


Growth. To obtain a time series for the determination of larval growth, shell length (15 to 25 individuals) was measured at Days 7, 10, 14, 17, 21 and 24. The growth rate $\left(\mu \mathrm{m} \mathrm{d}^{-1}\right)$ was calculated from the 6 replicates with the linear model: $\mathrm{SL}=a+b$ (Age -3$)$, where $\mathrm{SL}$ is the shell length $(\mu \mathrm{m}), a$ is the initial shell length $(\mu \mathrm{m})$ at Day $3, b$ is the growth rate $\left(\mu \mathrm{m} \mathrm{d}^{-1}\right)$ and Age is the age of the larvae $(\mathrm{d})$.

Development. The absence or presence of a foot was scored to determine larval development status. Development was expressed as the average percentage of larvae that had developed a foot (pediveliger and competent larvae), i.e. the average percentage of all replicates per food level. When possible, average values for age and shell length of larvae that had developed a foot were calculated with the logistic regressions: $\ln \left[p(1-p)^{-1}\right]=\alpha+b$ Age and $\ln \left[p(1-p)^{-1}\right]=\alpha+b S L$, respectively.

Mortality. Larval concentrations were measured at Days 3, 7, 10, 14, 17, 21 and 24. The concentration at Day 3 was considered as the initial concentration. Estimates of mortality were obtained by fitting a regression line through the natural logarithms of the concentrations against time, according to: $\ln \left(N_{t}\right)=$ $\ln \left(N_{0}\right)-r t$, where $N_{t}$ is the larval concentration at time $t$ (larvae $\mathrm{ml}^{-1}$ ), $N_{0}$ is the initial concentration (larvae $\left.\mathrm{ml}^{-1}\right), r$ is the mortality $\left(\mathrm{d}^{-1}\right)$ and $t$ is the age of the larvae (d).

Data analysis. Data on larval growth, development and mortality were normalised to correct for the effect of initial larval quality, which may vary among batches due to storage effects on the adults. For this purpose, data of the control treatment were set at $100 \%$ and the data of the SW1 and SW5 treatments were expressed relative to the control treatment (\%). Two-factor analysis of variance without replication (Zar 1996), referred to as 'analysis of variance' in the following sections, was used to determine the effect of fertilisation date and food level on larval growth, development and mortality.

\section{RESULTS}

\section{Larval food availability}

Analysis of the 53 phytoplankton taxa revealed only 5 taxa that were considered suitable for larval consumption: small flagellates $(<10 \mu \mathrm{m})$, Phaeocystis spp. single cells (probably all $P$. globosa), large flagellates (>10 $\mathrm{mm})$, Rhodomonas spp. and Katodinium rotundatum. Cells from the other taxa were not considered suitable, since they were either too large $(>20 \mu \mathrm{m})$ or formed chains or colonies.

The concentration of small flagellates varied between 420 and 2080 cells $\mathrm{ml}^{-1}$ from the beginning of April until the first week of May (Fig. 1). Subsequently, an increase of up to almost 5000 cells $\mathrm{ml}^{-1}$ was observed, decreasing to a level of 800 cells ml $\mathrm{m}^{-1}$ in the third week of May. The number of small flagellates accounted for $89 \%$ of the concentration of the suitable phytoplankton species in the study period, whilst Phaeocystis spp. single cells made up 3\%, Rhodomonas spp. $4 \%$ and large flagellates $4 \%$ (Fig. 1).

The food availability per batch was similar for Batches A, B, C and D, ranging between 1701 and 1790 cells $\mathrm{ml}^{-1}$ and then increased by approximately $25 \%$ to a level of ca. 2304 cells ml ${ }^{-1}$ for Batches E and F

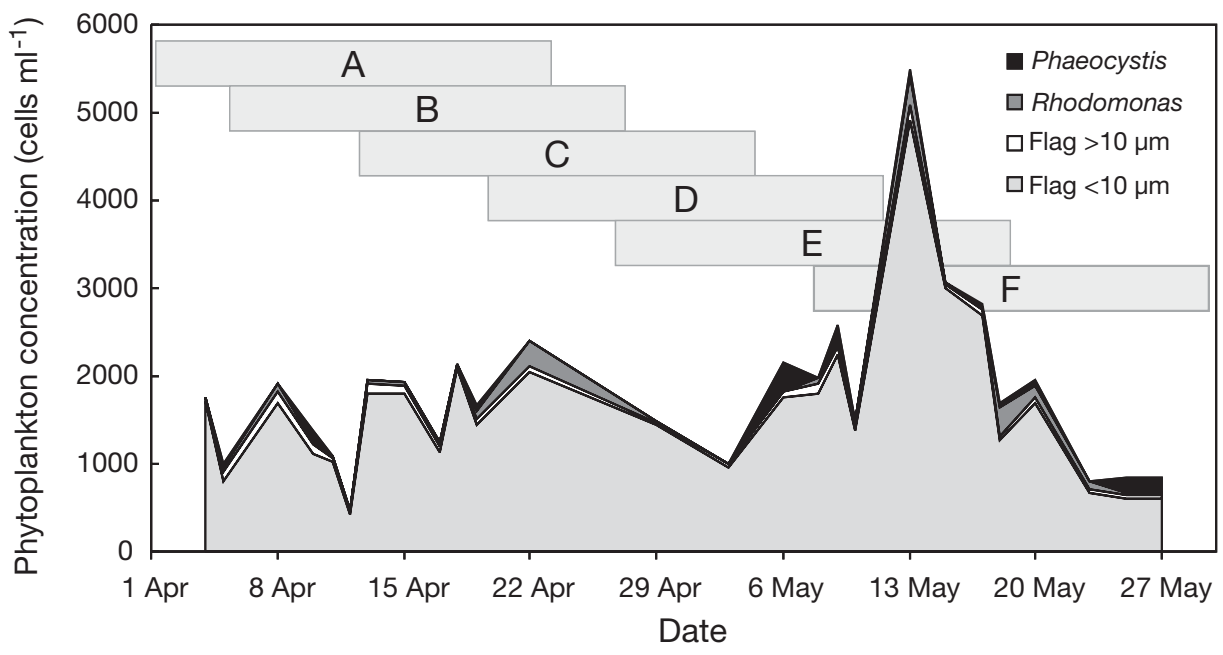

Fig. 1. Concentration of palatable phytoplankton taxa during the experimental period in the seawater used for the SW1 and SW5 food levels, including small flagellates $(<10 \mu \mathrm{m})$, large flagellates $(>10 \mu \mathrm{m})$, Rhodomonas spp. and Phaeocystis spp. single cells. The duration of the rearing period for each batch (A to F) of Macoma balthica larvae is indicated by blocks 
(Fig. 2). Small flagellates dominated the total food availability. Small flagellate availability for Batches A, $\mathrm{B}, \mathrm{C}$ and D ranged between 1491 and 1631 cells ml $^{-1}$ and then increased by approximately $25 \%$ to a level of ca. 2070 cells ml $\mathrm{m}^{-1}$ for Batches E and F. Phaeocystis spp. single cell concentration increased from 8 cells ml ${ }^{-1}$ in Batch A to 86 cells ml ${ }^{-1}$ in Batch F. Rhodomonas spp. cell concentration did not show a temporal trend, and

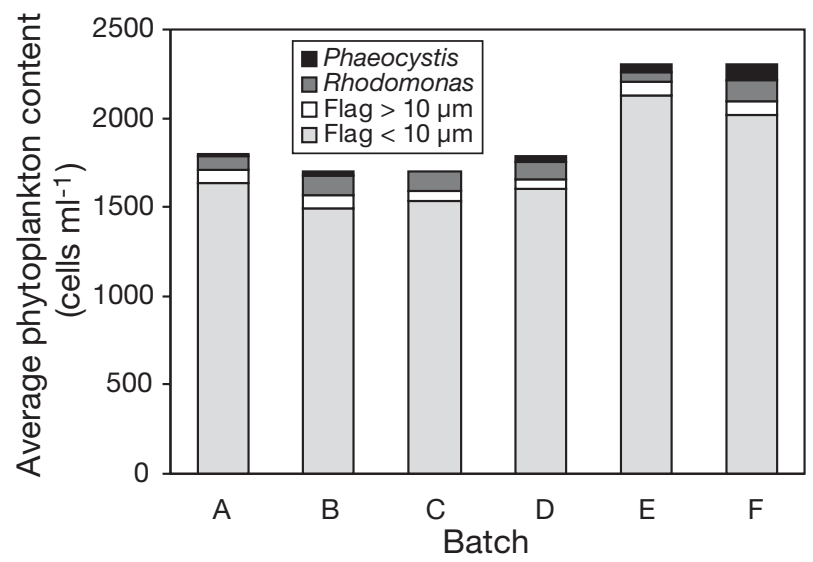

Fig. 2. Average food concentration (cells $\mathrm{ml}^{-1}$ ) for Macoma balthica larvae reared in natural seawater (food levels SW1 and SW5) during the $3 \mathrm{wk}$ rearing period for each of the batches (A to F), which were initiated at different times during the season. Phytoplankton species codes are the same as in Fig. 1 varied between 57 and 129 cells $\mathrm{ml}^{-1}$. Large flagellates did not show a trend in concentration either, and varied between 56 and 78 cells ml-1 (Fig. 2).

\section{Larval growth}

The initial shell length (mean $\pm \mathrm{SE}$ ) of the D-larvae at Day 3 varied between $149 \pm 1$ and $159 \pm 1 \mu$ m (Fig. 3). At Day 24, the shell length of larvae in the control food level varied between $221 \pm 6$ and $253 \pm 6 \mu \mathrm{m}$, in the SW1 food level between $188 \pm 4$ and $219 \pm 4 \mu \mathrm{m}$ and in the SW5 food level between $186 \pm 2$ and $231 \pm 5 \mu \mathrm{m}$ (Fig. 3). On average, larvae in the control food level grew $4.8 \pm 0.4 \mu \mathrm{m} \mathrm{d}^{-1}$, in the SW1 food level $2.7 \pm$ $0.4 \mu \mathrm{m} \mathrm{d}^{-1}$ and in the SW5 food level $2.4 \pm 0.4 \mu \mathrm{m} \mathrm{d}^{-1}$ (Table 2, Fig. 4).

Larvae subjected to food level SW1 in early April grew at a rate of $34 \%$ of those in the control food level, while in late May, they grew at a rate of about $70 \%$ (Fig. 4). Larvae subjected to food level SW5 grew more slowly than those in SW1 (Fig. 4). Analysis of variance of the normalised growth rates revealed a strongly significant effect of the timing of fertilisation and a significant effect of food level (Table 3). When the normalised growth rates were compared with the average phytoplankton availability, no correlation could be detected (SW1: $\mathrm{p}=0.092, \mathrm{r}^{2}=0.43$; SW5: $\mathrm{p}=0.25, \mathrm{r}^{2}=$ $0.12)$.

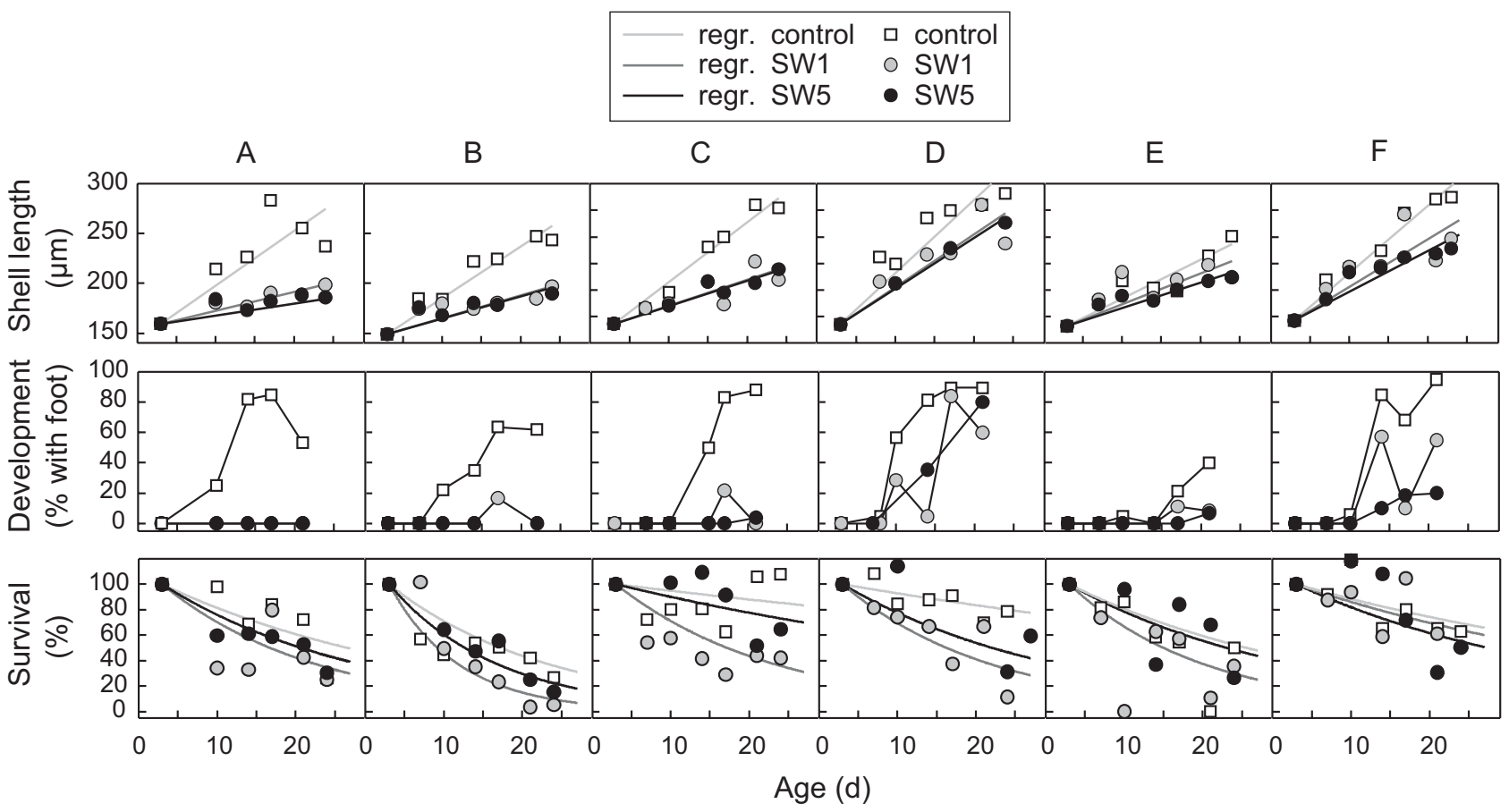

Fig. 3. Macoma balthica larvae. Shell length ( $\mu \mathrm{m}$; average of 15 to 25 individual larvae replicate ${ }^{-1}$ ), development (\% of larvae replicate $^{-1}$ that have developed a foot) and survival (\% of initial number of larvae replicate ${ }^{-1}$ that have survived), with regression lines showing growth $\left(\mu \mathrm{m} \mathrm{d}^{-1}\right)$ and mortality $\left(\mathrm{d}^{-1}\right)$ for larval Batches A to $\mathrm{F}$, which were initiated at different times during the season 
Table 2. Macoma balthica larvae. Growth rate $\left(\mu \mathrm{m} \mathrm{d}^{-1}\right)$, development, expressed as average percentage of larvae that have developed a foot $(\%)$, and mortality $\left(\mathrm{d}^{-1}\right)$. Normalised data expressed as percentage of control treatment. Bold values: means $\pm \mathrm{SE}$

\begin{tabular}{|c|c|c|c|c|c|c|c|c|c|c|c|}
\hline \multirow{2}{*}{ Code } & \multirow{2}{*}{$\begin{array}{l}\text { Batch } \\
\text { Start }\end{array}$} & \multirow[b]{2}{*}{ End } & \multicolumn{3}{|c|}{ Growth $\left(\mu \mathrm{m} \mathrm{d}^{-1}\right)$} & \multicolumn{3}{|c|}{ Development (\%) } & \multicolumn{3}{|c|}{ Mortality $\left(\mathrm{d}^{-1}\right)$} \\
\hline & & & SW1 & SW5 & Control & SW1 & SW5 & Control & SW1 & SW5 & Control \\
\hline \multicolumn{12}{|c|}{ Original data } \\
\hline A & 4 Apr & $25 \mathrm{Apr}$ & 1.9 & 1.5 & 5.5 & 0.00 & 0.00 & 40.86 & 0.050 & 0.039 & 0.029 \\
\hline B & $8 \mathrm{Apr}$ & 29 Apr & 2.3 & 2.2 & 5.2 & 2.38 & 0.00 & 26.11 & 0.112 & 0.071 & 0.049 \\
\hline $\mathrm{C}$ & 15 Apr & 6 May & 2.0 & 1.9 & 4.5 & 3.11 & 0.64 & 31.62 & 0.049 & 0.015 & 0.008 \\
\hline $\mathrm{D}$ & $22 \mathrm{Apr}$ & 13 May & 4.0 & 3.8 & 5.5 & 25.30 & 28.82 & 45.89 & 0.052 & 0.036 & 0.011 \\
\hline $\mathrm{E}$ & 29 Apr & 20 May & 2.3 & 1.9 & 3.0 & 2.78 & 0.95 & 9.42 & 0.058 & 0.035 & 0.031 \\
\hline $\mathrm{F}$ & 9 May & 30 May & 3.6 & 3.1 & 5.1 & 17.45 & 6.93 & 36.29 & 0.021 & 0.028 & 0.017 \\
\hline Mean & & & 2.7 & 2.4 & 4.8 & 8.5 & 6.2 & 31.7 & 0.057 & 0.037 & 0.024 \\
\hline $\mathrm{SE}$ & & & 0.4 & 0.4 & 0.4 & 4.2 & 4.6 & 5.3 & 0.012 & 0.008 & 0.006 \\
\hline \multicolumn{12}{|c|}{ Normalized data } \\
\hline $\mathrm{A}$ & 4 Apr & 25 Apr & 34 & 28 & 100 & 0 & 0 & 100 & 172 & 134 & 100 \\
\hline B & $8 \mathrm{Apr}$ & 29 Apr & 44 & 43 & 100 & 9 & 0 & 100 & 230 & 147 & 100 \\
\hline $\mathrm{C}$ & $15 \mathrm{Apr}$ & 6 May & 43 & 43 & 100 & 10 & 2 & 100 & 649 & 198 & 100 \\
\hline $\mathrm{D}$ & $22 \mathrm{Apr}$ & 13 May & 73 & 70 & 100 & 55 & 63 & 100 & 495 & 343 & 100 \\
\hline $\mathrm{E}$ & 29 Apr & 20 May & 79 & 65 & 100 & 29 & 10 & 100 & 188 & 113 & 100 \\
\hline $\mathrm{F}$ & 9 May & 30 May & 71 & 61 & 100 & 48 & 19 & 100 & 122 & 163 & 100 \\
\hline Mean & & & 56 & 51 & 100 & 27 & 20 & 100 & 237 & 156 & 100 \\
\hline $\mathrm{SE}$ & & & 8 & 7 & - & 13 & 15 & - & 50 & 32 & - \\
\hline
\end{tabular}
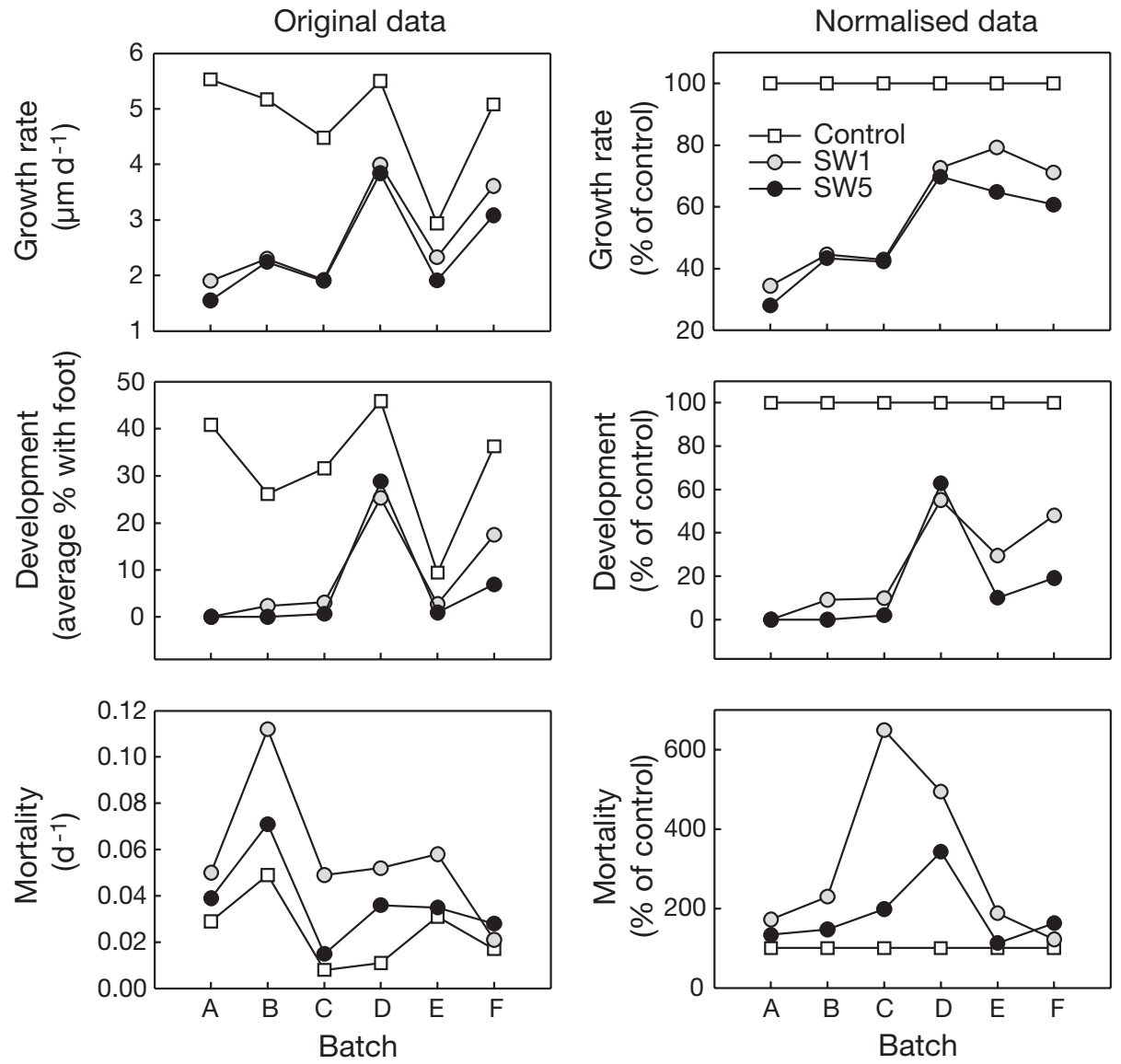

Fig. 4. Macoma balthica larvae. Growth, development and mortality of larvae reared on natural phytoplankton assemblages at 6 different times during the reproductive season. Left panels: growth rate $\left(\mu \mathrm{m} \mathrm{d}^{-1}\right)$, development rate (\% of larvae that have developed a foot; average of 5 replicates) and mortality $\left(\mathrm{d}^{-1}\right)$ per treatment. Right panels: normalised growth rate (\% of control group), normalised development rate (\% of control group) and normalised mortality rate (\% of control group); normalised rates serve to correct for differences in the initial larval quality 
Table 3. Macoma balthica larvae. Testing (2-factor analysis of variance without replication) for differences in normalised growth rate $(\%)$, normalised development rate (\%) and normalised mortality (\%) of larvae among manipulations of fertilisation date and food level. Bold values: $\mathrm{p}<0.05$

\begin{tabular}{|c|c|c|c|c|c|c|}
\hline Analysis of variance & Variable & SS & df & MS & $F$ & $\mathrm{p}$ \\
\hline $\begin{array}{l}\text { Normalised growth rate } \\
\left(\mathrm{n}=12, \mathrm{r}^{2}=0.98\right)\end{array}$ & $\begin{array}{l}\text { Fertilisation date } \\
\text { Food level } \\
\text { Error }\end{array}$ & $\begin{array}{r}3044.18 \\
106.41 \\
75.89\end{array}$ & $\begin{array}{l}5 \\
1 \\
5\end{array}$ & $\begin{array}{r}608.84 \\
106.41 \\
15.18\end{array}$ & $\begin{array}{r}40.11 \\
7.01\end{array}$ & $\begin{array}{r}<0.001 \\
0.046\end{array}$ \\
\hline $\begin{array}{l}\text { Normalised development rate } \\
\left(\mathrm{n}=12, \mathrm{r}^{2}=0.93\right)\end{array}$ & $\begin{array}{l}\text { Fertilisation date } \\
\text { Food level } \\
\text { Error }\end{array}$ & $\begin{array}{r}5076.53 \\
276.37 \\
432.46\end{array}$ & $\begin{array}{l}5 \\
1 \\
5\end{array}$ & $\begin{array}{r}1015.31 \\
276.37 \\
86.49\end{array}$ & $\begin{array}{r}11.74 \\
3.19\end{array}$ & $\begin{array}{l}\mathbf{0 . 0 0 8} \\
0.134\end{array}$ \\
\hline $\begin{array}{l}\text { Normalised mortality } \\
\left(\mathrm{n}=12, \mathrm{r}^{2}=0.76\right)\end{array}$ & $\begin{array}{l}\text { Fertilisation date } \\
\text { Food level } \\
\text { Error }\end{array}$ & $\begin{array}{l}1.87 \times 10^{-5} \\
4.78 \times 10^{-5} \\
7.30 \times 10^{-5}\end{array}$ & $\begin{array}{l}5 \\
1 \\
5\end{array}$ & $\begin{array}{l}3.73 \times 10^{-4} \\
4.78 \times 10^{-4} \\
1.46 \times 10^{-5}\end{array}$ & $\begin{array}{l}2.56 \\
3.28\end{array}$ & $\begin{array}{l}0.163 \\
0.130\end{array}$ \\
\hline
\end{tabular}

\section{Larval development}

In general, larvae in the control food levels were able to develop faster than in the SW1 and SW5 food levels (Figs. 3 \& 4). The percentage of larvae that had developed a foot (including pediveliger larvae) at Day 24 in the control food levels varied between 40 and $95 \%$. The logistic regression showed that the larvae in the control food level developed a foot, on average, in $18.8 \pm 1.5 \mathrm{~d}$ (mean $\pm \mathrm{SE}$ ), at a length of $231 \pm 3.3 \mu \mathrm{m}$. Most larvae that were offered natural seawater (food levels SW1 and SW5) in April (Batches A, B and C) did not develop into pediveligers at all, while a considerable fraction did develop a foot in the beginning of May (notably Batches D and F) (Fig. 3). In general, the percentage of larvae that had developed a foot at Day 24 in the SW1 food levels varied between 0 and $60 \%$, and in the SW5 food levels, between 0 and $80 \%$ (Table 2).

An analysis of variance of the normalised data on development of treatments SW1 and SW5 demonstrated a significant effect of the fertilisation date (Fig. 4, Table 3), but no effect of food level. When the normalised development rates were compared with the average phytoplankton availability, no correlation could be detected (SW1: $\mathrm{p}=0.31, \mathrm{r}^{2}=0.06$; SW5: $\mathrm{p}=$ $\left.0.94, \mathrm{r}^{2}=0.00\right)$.

\section{Larval mortality}

At Day 24, the concentration of larvae in the control food level varied between 79 and $26 \%$ (sensu Batch C: $108 \%$ ) of the initial concentration at Day 3, while the concentrations in the SW1 food levels varied between 42 and $5 \%$, and in the SW5 food levels, between 69 and $15 \%$ of the initial concentrations (Fig. 3). Average $( \pm \mathrm{SE})$ mortality rates of larvae in the control food level were $0.024 \pm 0.006 \mathrm{~d}^{-1}$; in the SW1 food level, $0.057 \pm$ $0.012 \mathrm{~d}^{-1}$; and in the SW5 food level, $0.037 \pm 0.008 \mathrm{~d}^{-1}$ (Table 2, Fig. 4).
An analysis of variance of the normalised data of Treatments SW1 and SW5 on mortality demonstrated no significant effects of fertilisation date or of food level (Table 3). When the normalised mortality rates were compared with the average phytoplankton availability, no correlation could be detected (SW1: $\mathrm{p}=0.21$, $\mathrm{r}^{2}=0.19$; SW5: $\left.\mathrm{p}=0.47, \mathrm{r}^{2}=0.00\right)$.

\section{DISCUSSION}

Philippart et al. (2003) hypothesised that a match/ mismatch mechanism of Macoma balthica larvae and their phytoplankton, at least partly, determines $M$. balthica recruitment. The current results show indeed that the timing of spawning affects the growth and development of $M$. balthica larvae. For example, in early April (Batch A), larvae in a concentration of 1 larva $\mathrm{ml}^{-1}$ in natural seawater (SW1) grew very slowly $\left(1.9 \mu \mathrm{m} \mathrm{d}^{-1}\right)$ and did not develop a foot $(0 \%)$, which points to a mismatch between larvae and their food source. Some weeks later, in the beginning of May (Batch D), larvae in SW1 had doubled their growth rates $\left(4.0 \mu \mathrm{m} \mathrm{d}^{-1}\right)$. Also, a relatively high percentage of larvae in SW1 had developed a foot (25\%) (Table 2). This increase indicates a match between larvae and their food source. Towards the end of May, both growth and development rates decreased to intermediate levels (Fig. 4), pointing to a mismatch again. In the experiment the temperature was kept constant at $15^{\circ} \mathrm{C}$.

The control food level served to correct for the effect of initial larval quality (normalisation). The results showed that the quality of the larvae in the controls was stable (Fig. 4), although some variation in growth, development and mortality of larvae was present, notably in Batch E (Fig. 4). Such variation may have been caused by differences in adult condition due to storage effects (Lannan 1980) or due to the outbreak of bacterial or viral infections (review in Elston 1993). 
Alternatively, it may have been caused by the differences in genetic constitution of the parents and, hence, of the larvae (e.g. Hilbish et al. 1999), although this is less probable since larvae in each batch originated from a random group of parents that all originated from the same population. Whatever the cause of variation, from Fig. 4 it is clear that the same variation applied to the SW1 and SW5 food levels, i.e. the data for the SW1 and SW5 food levels co-varied with the data for the control food level.

Normalised growth and development rates were clearly affected by fertilisation date (Table 3), while normalised mortality was not. This demonstrates that the timing of spawning is of great importance for bivalve larvae and that the differences in growth and development rates must have been caused by the differences in the food content of the seawater. Furthermore, the normalised growth rate was affected by food level, while the normalised development and mortality rates were not (Table 3). This suggests that resource or interference competition (Keddy 1989) reduced the intake rate of the larvae at the SW5 food levels as compared to the SW1 food levels.

The recorded growth rates of 3.0 to $5.5 \mu \mathrm{m} \mathrm{d}^{-1}$ for Macoma balthica larvae in the control food level compare well to larval growth rates observed by Drent (2002) of $5.2 \mu \mathrm{m} \mathrm{d}^{-1}$. The recorded average age (18.8 d) and size $(231 \mu \mathrm{m})$ at the moment of the appearance of a foot were slightly lower than the values of $20.6 \mathrm{~d}$ and $254 \mu \mathrm{m}$, respectively, as observed by Drent (2002). The average growth rates in the SW1 $\left(2.7 \mu \mathrm{m} \mathrm{d}^{-1}\right)$ and SW5 $\left(2.4 \mu \mathrm{m} \mathrm{d}^{-1}\right)$ food levels were very low compared to those in the control level, but compared well to growth rates of 1.0 to $3.1 \mu \mathrm{m} \mathrm{d}^{-1}$ of Mytilus edulis larvae at food levels of 1 to $3 \times 10^{4}$ cells Isochrysis ml ${ }^{-1}$ (Pechenik et al. 1990). Finally, the recorded mortality rates of 0.037 to $0.057 \mathrm{~d}^{-1}$ were in line with those observed by Drent (2002), but lower than the natural daily mortality rates of meroplanktonic larvae of 0.13 to $0.28 \mathrm{~d}^{-1}$ (review in Rumrill 1990). This is probably due to absence of predators and diseases under in vitro conditions.

The observed time effects on growth, development and mortality of Macoma balthica larvae reared in natural seawater (SW1 and SW5) could not be explained by phytoplankton abundance, since the average phytoplankton cell concentration only slightly increased through time (Fig. 2). Based on long-term phytoplankton observations ( $>30 \mathrm{yr}$ ), it was expected to observe a change from low cell numbers $\left(2 \times 10^{3}\right.$ cells ml $\left.{ }^{-1}\right)$ at the start of the bloom to high numbers $(2 \times$ $10^{5}$ cells $\mathrm{ml}^{-1}$ ) some weeks later (Cadée 1986). Instead, phytoplankton cell concentrations remained relatively low during the entire experimental period. Chlorophyll $a(\mathrm{chl} a)$ data for the same period confirmed the results
(G. C. Cadée unpubl. data). A phytoplankton bloom came after all, but only in June 2002 when the chl a content amounted to $178 \%$ of the long-term average (G. C. Cadée unpubl. data). Although the results do not support the original match/mismatch hypothesis that is defined in terms of quantities of prey and predators (Cushing 1975), it is clear that there is a time effect, probably caused by a change in the food content of the seawater during the experimental period.

One explanation for the observed effects is that the species composition and, hence, the nutritional quality of the small flagellates may have changed over time, while total phytoplankton cell numbers remained more or less constant, which is in line with the results of Beaugrand et al. (2003). Previous studies have demonstrated that growth rates often cannot be explained by variation in phytoplankton concentrations or phytoplankton consumption alone (Pechenik \& Fisher 1979). The biochemical composition of the phytoplankton also has a large impact on the growth and development rates of plankton (Wacker et al. 2002, Klein Breteler et al. 2005). In addition, larvae may selectively feed on phytoplankton according to growth rate and chemical content (Baldwin 1995).

Macoma balthica may be more sensitive to a match/mismatch with phytoplankton in spring than other bivalve species in the Wadden Sea that spawn later in the season (Honkoop \& Van der Meer 1998). For example, Mytilus edulis spawns in response to phytoplankton blooms (Starr et al. 1990), and therefore the larvae will probably be subjected to starvation less frequently. Since $M$. balthica juveniles may be consumed by predators such as size-selective shrimp and shore-crabs (Beukema 1992, Hiddink et al. 2002), the strategy of $M$. balthica to spawn early at the cost of a possible mismatch between larvae and phytoplankton may have been developed to avoid predators and reduce juvenile mortality (Philippart et al. 2003). This suggests that $M$. balthica is an 'early strategist' (Fortier et al. 1995). Due to the rising seawater temperatures in the Wadden Sea, a mismatch between $M$. balthica larvae and their food is likely to occur more frequently in the future, since the spawning period of $M$. balthica is moved to an earlier time in the year, while the onset of the phytoplankton bloom is not affected (Philippart et al. 2003). In addition, mild winters decrease the reproductive output of $M$. balthica and advance shrimp predation (Philippart et al. 2003). Together these factors may result in a decline of the $M$. balthica population and, possibly, long term, in a selection for laterbreeding $M$. balthica. Besides climate-related changes, other factors such as pollutants and discharged pharmaceuticals from sewage treatment plants may affect the timing of spawning of bivalves in the Wadden Sea by delaying or speeding up the 
spawning time (e.g. Honkoop et al. 1999). In our study area, however, neither concentrations of pharmaceuticals nor their effects on aquatic organisms have been determined yet (Schrap et al. 2003).

In conclusion, a clear effect of the timing of spawning of adult Macoma balthica on the growth and development of their offspring was detected in the current experiment. However, these differences could not be attributed to temporal changes in phytoplankton concentrations. This suggests that food quality may have changed over time. To determine the nutritional value of different phytoplankton species for $M$. balthica larvae, laboratory experiments may be used (Volkman et al. 1989, Jonsson et al. 1999). In addition, diet choice experiments could be performed to estimate ingestion rates of different species of phytoplankton by $M$. balthica larvae. To gain insight into feeding preferences in the field, larval stomach contents could be determined (Raby et al. 1997).

Acknowledgements. W. J. Wolff, S. P. Holmes and 4 anonymous reviewers made valuable comments on earlier drafts. Funding for this study was provided by the Netherlands Organisation for Scientific Research (Priority Program on Conservation and Sustainable Use of Marine Living Resources).

\section{LITERATURE CITED}

Baldwin BS (1995) Selective particle ingestion by oyster larvae (Crassostrea virginica) feeding on natural seston and cultured algae. Mar Biol 123:95-107

Beaugrand G, Brander KM, Alistair Lindley J, Souissi S, Reid PC (2003) Plankton effect on cod recruitment in the North Sea. Nature 426:661-664

Beukema JJ (1992) Dynamics of juvenile shrimp Crangon crangon in a tidal-flat nursery of the Wadden Sea after mild and cold winters. Mar Ecol Prog Ser 83:157-165

Cadée GC (1986) Recurrent and changing seasonal patterns in phytoplankton of the westernmost inlet of the Dutch Wadden Sea from 1969 to 1985. Mar Biol 93:281-289

Cushing DH (1975) Marine ecology and fisheries. Cambridge University Press, Cambridge

Cushing DH (1990) Plankton production and year-class strength in fish populations: an update of the match/mismatch hypothesis. Adv Mar Biol 26:249-294

Drent J (2002) Temperature responses in larvae of Macoma balthica from a northerly and southerly population of the European distribution range. J Exp Mar Biol Ecol 275: $117-129$

Elston RA (1993) Infectious diseases of the Pacific oyster, Crassostrea gigas. Annu Rev Fish Dis 3:259-276

Fortier L, Ponton D, Gilbert M (1995) The match/mismatch hypothesis and the feeding success of fish larvae in icecovered southeastern Hudson Bay. Mar Ecol Prog Ser 120: $11-27$

Gotceitas V, Puvanendran V, Leader L, Brown J (1996) An experimental investigation of the 'match/mismatch' hypothesis using larval Atlantic cod. Mar Ecol Prog Ser 130:29-37

Hiddink JG, Marijnissen SAE, Troost K, Wolff WJ (2002) Predation on 0-group and older year classes of the bivalve Macoma balthica: interaction of size selection and inter- tidal distribution of epibenthic predators. J Exp Mar Biol Ecol 269:223-248

Hilbish TJ, Sasada K, Eyster LS, Pechenik JA (1999) Relationship between rates of swimming and growth in veliger larvae: genetic variance and covariance. J Exp Mar Biol Ecol 239:183-193

Honkoop PJC, Van der Meer J (1998) Experimentally induced effects of water temperature and immersion time on reproductive output of bivalves in the Wadden Sea. J Exp Mar Biol Ecol 220:227-246

Honkoop PJC, Luttikhuizen PC, Piersma T (1999) Experimentally extending the spawning season of a marine bivalve using temperature change and fluoxentine as synergistic triggers. Mar Ecol Prog Ser 180:297-300

Jonsson PR, Berntsson KM, André C, Wängberg S-Å (1999) Larval growth and settlement of the European oyster (Ostrea edulis) as a function of food quality measured as fatty acid composition. Mar Biol 134:559-570

Keddy PA (1989) Competition. Chapman \& Hall, London

Klein Breteler WCM, Schogt N, Rampen S (2005) Effect of diatom nutrient limitation on copepod development: role of essential lipids. Mar Ecol Prog Ser 291:125-133

Lammens JJ (1967) Growth and reproduction of a tidal flat population of Macoma balthica (L.). Neth J Sea Res 3:315-382

Lannan JE (1980) Broodstock management of Crassostrea gigas. I. Genetic and environmental variation in survival in the larval rearing system. Aquaculture 21:337-345

Olson RR, Olson MH (1989) Food limitation of planktotrophic marine invertebrate larvae: Does it control recruitment success? Annu Rev Ecol Syst 20:225-247

Pechenik JA, Fisher NS (1979) Feeding, assimilation, and growth of mud snail larvae, Nassarius obsoletus (Say), on three different algal diets. J Exp Mar Biol Ecol 38:57-80

Pechenik JA, Eyster LS, Widdows J, Bayne BL (1990) The influence of food concentration and temperature on growth and morphological differentiation of blue mussel Mytilus edulis L. larvae. J Exp Mar Biol Ecol 136:47-64

Philippart CJM, Van Aken HM, Beukema JJ, Bos OG, Cadée GC, Dekker R (2003) Climate-related changes in recruitment of the bivalve Macoma balthica. Limnol Oceanogr 48:2171-2185

Phillips NE (2002) Effects of nutrition-mediated larval condition on juvenile performance in a marine mussel. Ecology 83:2562-2574

Platt T, Fuentes-Yaco C, Frank KT (2003) Spring algal bloom and larval fish survival. Nature 423:398-399

Raby D, Mingelbier M, Dodson JJ, Klein B, Lagadeuc Y, Legendre L (1997) Food-particle size and selection by bivalve larvae in a temperate embayment. Mar Biol 127: 665-672

Rumrill SS (1990) Natural mortality of marine invertebrate larvae. Ophelia 32:163-198

Schrap SM, Rijs GBJ, Beek MA, Maaskant JFN, Staeb J, Stroomberg G, Tiesnitsch J (2003) Humane en veterinaire geneesmiddelen in Nederlands oppervlaktewater en afvalwater: een screening in 2002. Report No. 2003.023, RIZA, Lelystad

Starr M, Himmelman JH, Therriault JC (1990) Direct coupling of marine invertebrate spawning with phytoplankton blooms. Science 247:1071-1074

Volkman JK, Jeffrey SW, Nichols PD, Rogers GI, Garland CD (1989) Fatty-acid and lipid composition of ten species of microalgae used in mariculture. J Exp Mar Biol Ecol 128: 219-240

Wacker A, Becher P, Von Elert E (2002) Food quality effects of unsaturated fatty acids on larvae of the zebra mussel Dreissena polymorpha. Limnol Oceanogr 47:1242-1248

Zar JH (1996) Biostatistical analysis. Prentice Hall, London 